\title{
Nitric Oxide Airway Diffusing Capacity and Mucosal Concentration in Asthmatic Schoolchildren
}

\author{
CHRISTOPHE PEDROLETTI, MARIEANN HÖGMAN, PEKKA MERILÄINEN, \\ LENNART S. NORDVALL, GUNILLA HEDLIN, AND KJELL ALVING
}

\begin{abstract}
Departments of Woman and Child Health [C.P., G.H.] and Physiology and Pharmacology [K.A.], Karolinska Institutet, SE-171 77 Stockholm, Sweden; Departments of Medical Cell Biology [M.H.] and Woman and Child Health [L.S.N.], Uppsala University, SE-751 05 Uppsala, Sweden; and Datex-Ohmeda Research Department, SF-00031 Helsinki, Finland [P.M.]
\end{abstract}

\begin{tabular}{|c|c|}
\hline \multicolumn{2}{|c|}{ ABSTRACT } \\
\hline 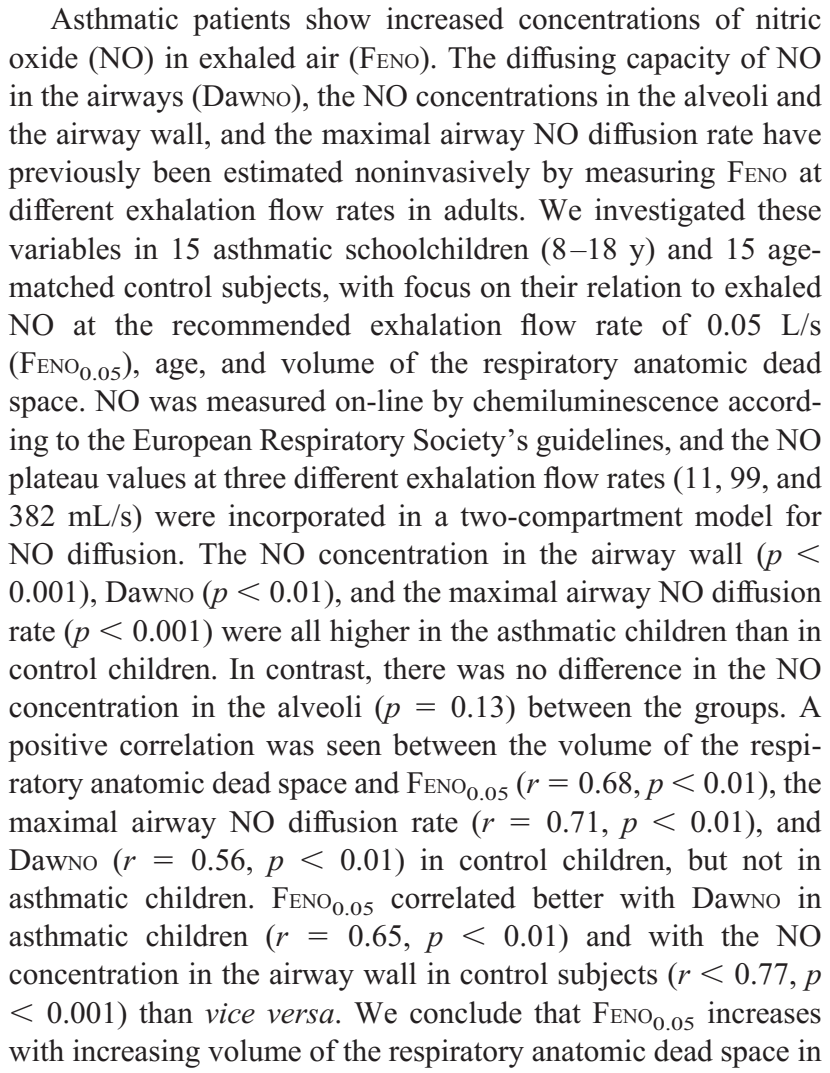 & 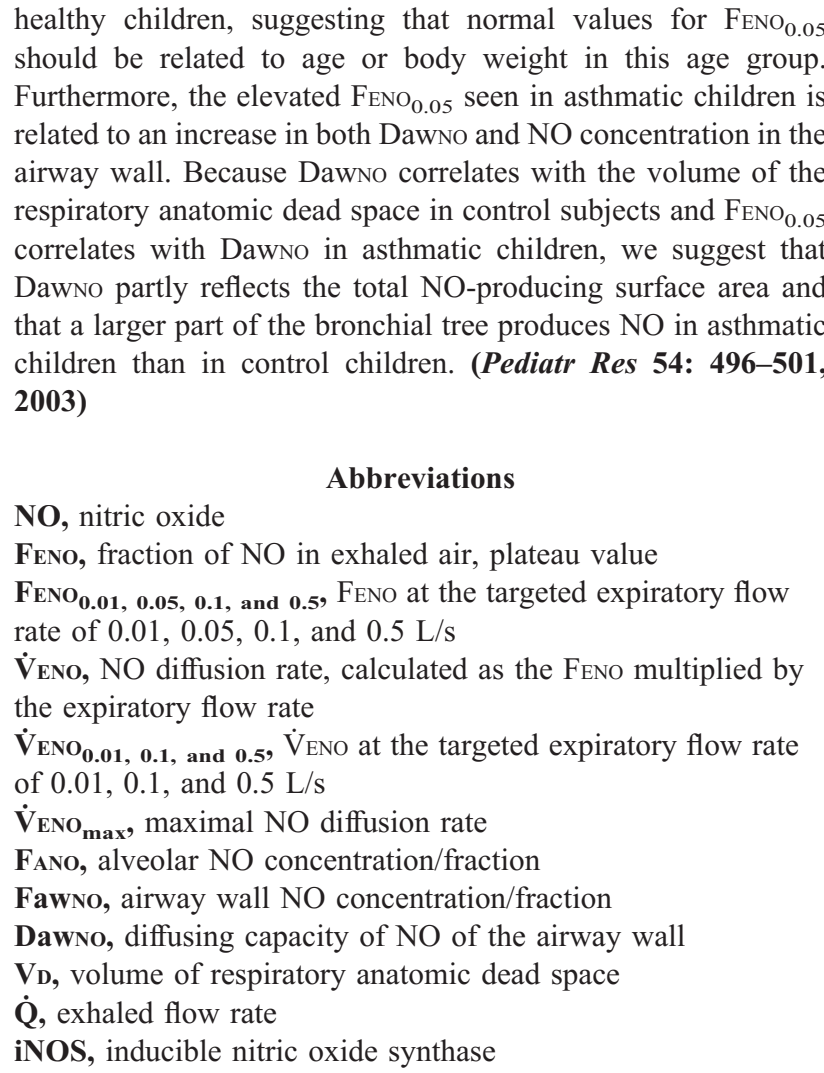 \\
\hline
\end{tabular}

NO can be measured in exhaled air, and high levels of NO are believed to reflect allergic inflammation in the airways of

Received July 8, 2002; accepted December 3, 2002.

Correspondence: Christophe Pedroletti, M.D., Department of Allergy Q2:04, Astrid Lindgren Children's Hospital, Karolinska Hospital, SE-171 76 Stockholm, Sweden; e-mail: christophe.pedroletti@ks.se

Supported by the Swedish Heart Lung Foundation, Swedish Asthma and Allergy Association's Research Foundation, Samariten Foundation, Swedish Foundation for Health Care Science and Allergy Research, Consul ThC Bergh Foundation, and the asthmatic patients (1-3). Correlations between exhaled NO and other markers of airway inflammation such as eosinophils in sputum and blood (4-6), bronchial hyperresponsiveness (7), and bronchial eosinophilia $(5,8)$ have been demonstrated. In the lower airways, NO is thought to be produced by iNOS in

Swedish Research Council-Medicine (Project No. 10354).

DOI: 10.1203/01.PDR.0000081761.33822.36 
the epithelial cells (9). The mechanisms that regulate iNOS induction are not fully understood, but there is evidence for both transcriptional and posttranslational regulation of $\mathrm{NO}$ synthesis in human epithelial cells (10). Because NO is produced in the conducting airways, the concentration of NO in exhaled gas will be flow-dependent (11). Therefore, a targeted exhalation flow rate of $50 \mathrm{~mL} / \mathrm{s}$ has been suggested by the American Thoracic Society (12) to make data comparable. The NO plateau value is usually presented as the Feno in parts per billion.

However, a few investigators have put a lot of effort into measuring exhaled $\mathrm{NO}$ at multiple exhalation flow rates, to gain more information on NO formation in the lower respiratory tract (13-17). Some of these investigators have proposed models for NO diffusion in which alveolar and airway mucosal NO concentrations can be estimated. The general concept of these models is basically the same, and the equations do not differ extensively. The airways are approximated to a twocompartment model: the alveolar region and the conducting airways. NO is primarily produced within the airway wall, diffusing in a concentration-dependent manner into the airway lumen during exhalation. If FENO is determined at several suitable exhalation flow rates, effective Fawno, Dawno, FAno, and $\dot{\mathrm{V}}_{\mathrm{ENO}}$ max can be estimated (13).

The aim of our study was to estimate these variables in a group of schoolchildren with and without asthma. We used a method of approximate linear regression analysis with a computerized iteration process recently described by Högman et al. (17). This method has been shown to be numerically robust and allows estimation of the above-mentioned variables with only three different exhalation flow rates. Furthermore, to learn more about NO diffusion in human airways, we also wanted to study the relation of these variables to $\mathrm{FENO}_{0.05}$, and subject characteristics such as age and $V_{D}$.

\section{METHODS}

Feno and exhalation flow rate data from 15 asthmatic schoolchildren (age 8-18 y; mean, 14 y) with elevated Feno levels and 15 age-matched control children were used in the model.
The children were randomly recruited from the Allergy Clinic at Astrid Lindgren Children's Hospital, Karolinska Hospital.

Thirteen of these 15 asthmatic children had atopic asthma and were sensitized to furry pets, pollen, or house dust mite. Atopy was evaluated by skin-prick testing. Five children were steroid-naïve. Median dose of inhaled steroids was $100 \mu \mathrm{g} / \mathrm{d}$ in steroid-treated patients. A brief structured interview regarding symptoms was performed on the day of examination. Fifteen nonatopic, nonasthmatic children (age 8-18 y; mean, $12 \mathrm{y}$ ), six girls and nine boys, without history of atopy or heredity for atopic disease served as control subjects. They were selected regardless of NO levels. Subjects with either a recent history of respiratory tract infection ( $7 \mathrm{~d}$ prior to the study) or signs of respiratory tract infection on the day of examination were not accepted in the study. Pubertal girls were not examined during menstruation. All children were nonsmokers. All subjects completed the study. Medication and other subject characteristics are described in Table 1. VD was calculated as the body weight (in kilograms) multiplied by $2 \mathrm{~mL}$ (18).

NO measurements. Measurements were performed in accordance with international recommendations for on-line NO measurements previously described in the European Respiratory Society Task Force Report (19). The data used in the study were, however, originally obtained to study reproducibility of Feno at different flow rates (20). Therefore, individual variations in exhalation flow rate and Feno levels were accepted and registered, as long as the flow rate was kept constant and an Feno plateau was achieved during the exhalation. We used the Aerocrine NO system (Aerocrine AB, Stockholm, Sweden), including the CLD 77 AM chemiluminescence analyzer from Eco Physics AG (Dürnten, Switzerland) for on-line NO measurements and monitoring of pressure. The sensitivity of the analyzer is $0.1 \mathrm{ppb}$, the rise time from 0 to $90 \%$ is $0.1 \mathrm{~s}$, the sampling flow rate $110 \mathrm{~mL} / \mathrm{min}$, and the machine lag time from the mouthpiece $0.7 \mathrm{~s}$. The children were comfortably seated, inhaled NO-free air from a reservoir, and subsequently exhaled against different linear resistors (Hans Rudolph Inc, Kansas City, MO, U.S.A.). The target oral pressure at the different flow rates was $10 \mathrm{~cm} \mathrm{H}_{2} \mathrm{O}$. As support in this maneuver, the children

Table 1. Subject characteristics

\begin{tabular}{|c|c|c|c|c|c|c|c|c|}
\hline \multicolumn{6}{|c|}{ Asthmatics } & \multicolumn{3}{|c|}{ Controls } \\
\hline Age (y) & Sex & $\mathrm{V}_{\mathrm{D}}(\mathrm{mL})$ & Atopy & Medication & Inhaled steroids $(\mu \mathrm{g} / \mathrm{d})$ & Age & Sex & $\mathrm{VD}(\mathrm{mL})$ \\
\hline 17.2 & M & 200 & yes & No medication & 0 & 15.9 & M & 132 \\
\hline 18.3 & M & 118 & yes & No medication & 0 & 10.8 & M & 56 \\
\hline 11.0 & M & 72 & yes & Budesonide & 100 & 18.7 & M & 128 \\
\hline 14.1 & M & 78 & yes & Budesonide & 100 & 16.5 & M & 134 \\
\hline 15.8 & M & 106 & yes & Fluticasone propionate & 250 & 10.2 & M & 64 \\
\hline 13.1 & M & 124 & yes & Budesonide & 400 & 8.1 & M & 48 \\
\hline 15.0 & M & 168 & no & Fluticasone propionate & 400 & 13.8 & M & 138 \\
\hline 13.3 & M & 126 & yes & Fluticasone propionate & 500 & 8.2 & $\mathrm{~F}$ & 62 \\
\hline 13.0 & M & 100 & yes & Fluticasone propionate (and salmeterol 100) & 500 & 11.0 & M & 86 \\
\hline 13.1 & $\mathrm{~F}$ & 96 & yes & Fluticasone propionate (and salmeterol 100) & 100 & 16.1 & M & 126 \\
\hline 11.9 & $\mathrm{~F}$ & 90 & yes & Chromoglycate & 0 & 13.1 & $\mathrm{~F}$ & 96 \\
\hline 17.5 & M & 148 & yes & Fluticasone propionate (and montelukast $10 \mathrm{mg}$ ) & 500 & 9.1 & $\mathrm{~F}$ & 58 \\
\hline 10.1 & $\mathrm{~F}$ & 112 & yes & No medication & 0 & 11.1 & $\mathrm{~F}$ & 96 \\
\hline 15.8 & M & 116 & yes & Budesonide & 200 & 10.7 & $\mathrm{~F}$ & 76 \\
\hline 8.1 & M & 64 & yes & Chromoglycate & 0 & 11.3 & $\mathrm{~F}$ & 96 \\
\hline
\end{tabular}


were given a target pressure between two indicator lines at 8 and $12 \mathrm{~cm} \mathrm{H}_{2} \mathrm{O}$. Resistors were changed between exhalations. We used the following resistors: $20,100,200$, and $1000 \mathrm{~cm}$ $\mathrm{H}_{2} \mathrm{O} \cdot \mathrm{mL} \cdot \mathrm{s}$ to get target flow rates of $500,100,50$, and 10 $\mathrm{mL} / \mathrm{s}$.

NO and flow calculations. Mean FENO was calculated during an Feno plateau of $3 \mathrm{~s}$. A plateau was approved when Feno did not vary more than $10 \%$ or $\pm 1 \mathrm{ppb}$.

Flow was calculated as the ratio between pressure and resistance and was corrected for analyzer sample flow rate. Values from three consecutive exhalations at each targeted flow rate were registered and fitted into the model.

Extended NO analysis. The model used in this study has been described in detail elsewhere (17). Briefly, it is based on the relationship between FENO and the NO formation in the two compartments: the alveolar region and the conducting airway tube. Four variables are estimated in the model: Fawno, FANO, Dawno, and $\dot{\mathrm{VNNO}}_{\max }$. The mathematical elaboration based on standard physics of diffusion gives the basic equation for FENO as a function of Q: Equation, msp 8

$$
\text { FENO }=\text { FawnO }-(\text { FawnO }- \text { FANO }) \cdot e^{- \text {Dawno } / \dot{Q}}
$$

For three unknown variables at least three data points are required. As suggested by Tsoukias and George (13), FANO and $\dot{\mathrm{V}}_{\mathrm{ENO}}$ max are calculated from the almost linear slope between, for example, $\dot{\mathrm{V}}_{\mathrm{ENO}} . .5$ and $\dot{\mathrm{V}}_{\mathrm{ENO}}{ }_{0.1}$. Then Dawno is solved by finding the intercept of the $\dot{V}_{\text {ENO }}$ axis and the line used for defining the slope, and thereafter a computer-powered iterative algorithmic process is used to solve Dawno. In a final step the accuracy is improved further still by using a second-order iteration to correct for the minimal alinearity in the FANO slope (17). Once Fano and Dawno have been estimated, Fawno can be calculated. This approach is a robust alternative to the sometimes more problematic least-square fit method in which more data points are needed at more extreme exhalation flow rates $(<10$ and $>400 \mathrm{~mL} / \mathrm{s})$ in the Feno-flow plot curve (16). Because the reproducibility of the FENo data are known to be decreased at more extreme flows (20), it can severely affect the curve fit quality.

Statistical procedures. We used Prism 3 software (Graph Pad Software Inc, San Diego, CA, U.S.A.) for statistical analyses. Nonparametric tests were applied as the distribution of these variables is not known and our material was too small for normal distribution analysis. Data are expressed as arithmetic mean \pm SEM unless otherwise stated. To study correlations we used the Spearman rank correlation test. A $p$ value of less than 0.05 was considered significant.

Ethics. The study was approved by the regional ethics committee at the Karolinska Institute, and the children and their parents gave their informed consent before inclusion.

\section{RESULTS}

General results. All subjects completed the study. The FENO values were highly flow-dependent, and the difference between groups was significant at all flow rates $(p<0.001$, all).

Dawno, Fawno, FANo, and $\dot{V}_{E N o_{m a x}}$ Asthmatic children showed significantly higher levels for all these variables except for Fano (Dawno, $26.3 \pm 3.2$ versus $13.2 \pm 1.7 \mathrm{~nL} \cdot \mathrm{s}^{-1}$. $\mathrm{ppb}^{-1} \times 10^{-3}$; Fawno, $154.2 \pm 23.3$ versus $54.6 \pm 8.4 \mathrm{ppb}$; FANO, $1.5 \pm 0.2$ versus $1.2 \pm 0.1 \mathrm{ppb} ; \dot{\mathrm{V}}_{\mathrm{ENO}} \max , 3.5 \pm 0.4$ versus $0.7 \pm 0.1 \mathrm{~nL} / \mathrm{s}$; asthmatic and control children, respectively). The scatter diagrams for these variables and $\mathrm{FeNO}_{0.05}$ are shown in Figures 1 and 2. Even though there was no overlap in $\mathrm{FeNO}_{0.05}$ between the groups, Fawno and Dawno overlapped considerably. However, the combination of both a high Fawno and a high Dawno was not seen in the control group. We could not find any difference in $\mathrm{FENO}_{0.05}$ values or in the estimated variables between steroid-treated and steroidnaïve asthmatic children (not shown).

Correlations. A summary of all the correlations is shown in Table 2. We found a strong correlation between $\mathrm{FENO}_{0.05}$ and $\dot{\mathrm{V}}_{\mathrm{ENO}} \max$ in both groups. However, when Fawno and Dawno were studied separately, $\mathrm{FENO}_{0.05}$ correlated better with Dawno in asthmatic children and with Fawno in control children. FANO showed no correlation at all with $\mathrm{FENO}_{0.05}$, the estimated variables, or $V_{D}$ and age (not shown). A positive correlation between $\mathrm{VD}_{\mathrm{D}}$ and $\mathrm{FENO}_{0.05}, \dot{\mathrm{VENO}}_{\max }$, and Dawno, was seen in the control group but not in the asthma group. Even though $V_{D}$ and
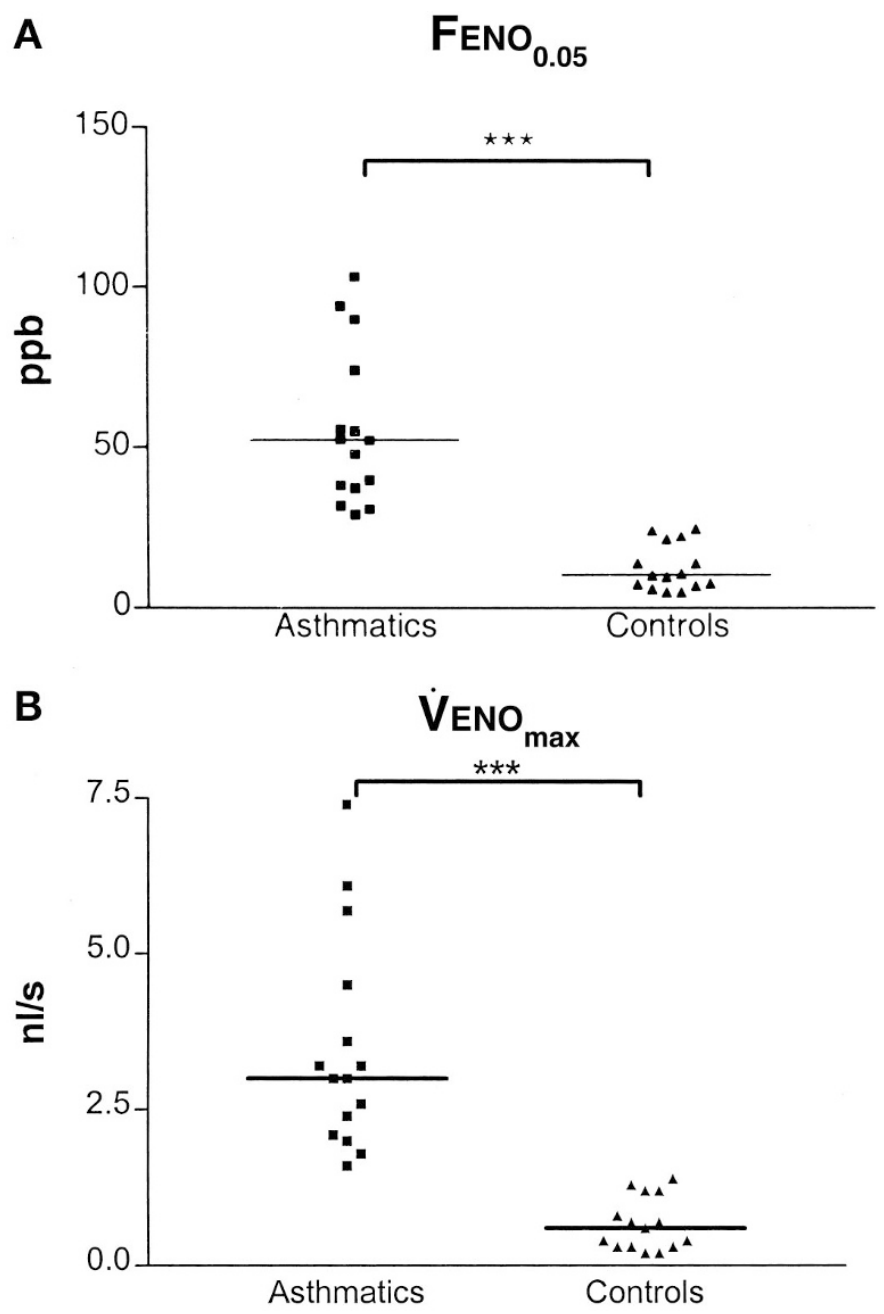

Figure 1. Levels of $\mathrm{FeNO}_{0.05}$ (left) and the estimated level of $\dot{\mathrm{VENO}}_{\text {max }}$ (right) in 15 asthmatic schoolchildren and 15 age-matched control subjects. ${ }^{* * *} p<$ 0.001 (Mann-Whitney $U$ test). The bars indicate median values. 
A

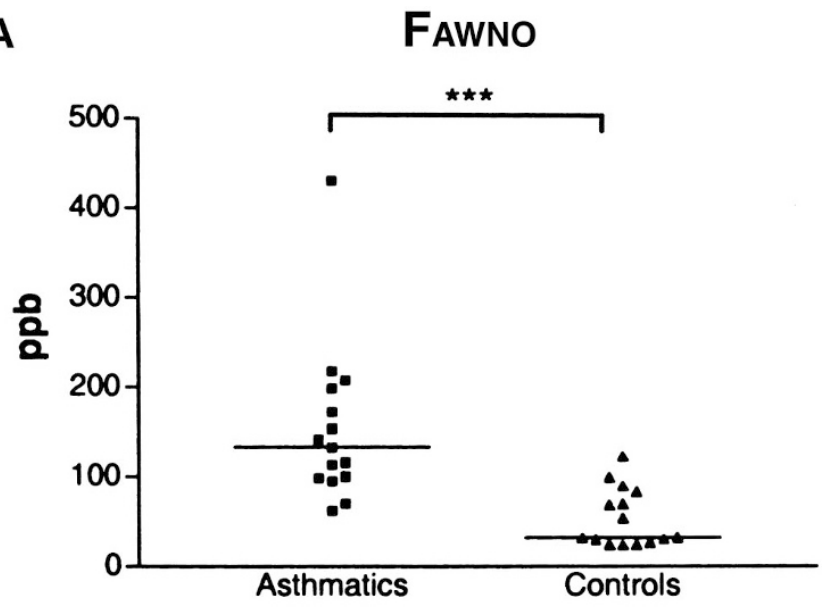

B

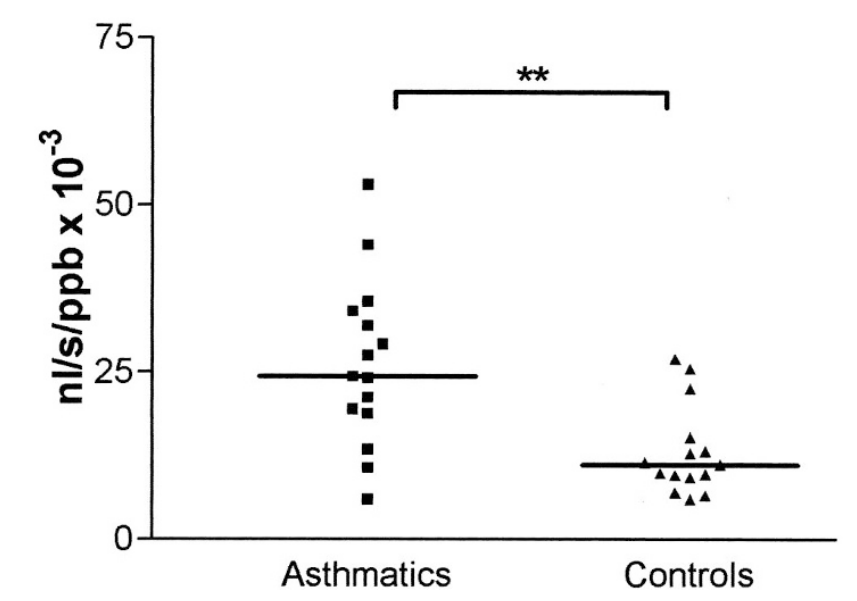

C

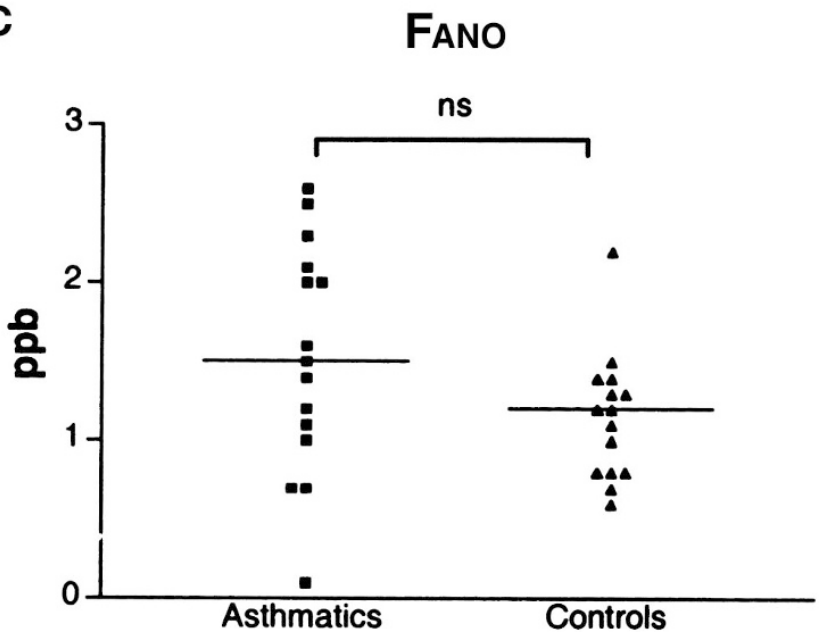

Figure 2. Estimated levels of Fawno (left) and Fano (center) and the Dawno (right) in 15 asthmatic schoolchildren and 15 age-matched control subjects. ${ }^{* *} p<0.01,{ }^{* * *} p<0.001$ (Mann-Whitney $U$ test); ns, not significant. The bars indicate median values.

Fawno did not seem be related to each other in either group, a significant correlation between Fawno and age could be demonstrated in control children.

To validate the model and the mathematical solutions, we checked for a correlation between expected (see "Methods,"

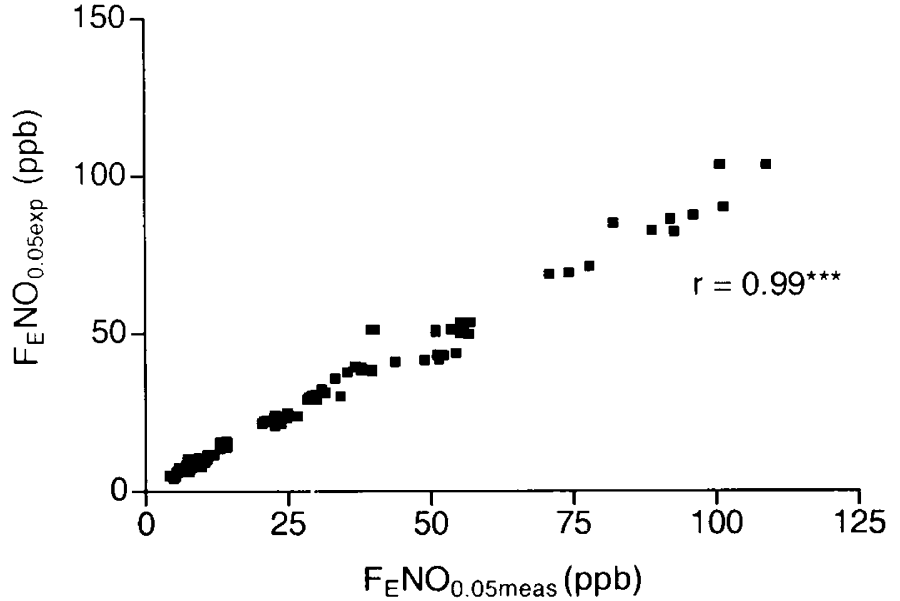

Figure 3. The correlation between expected and measured $\mathrm{FeNO}_{0.05}(n=89$ exhalations in 30 asthmatic and healthy schoolchildren). The expected values were calculated by using the estimated variables and measured flow at the targeted exhalation flow rate of $50 \mathrm{~mL} / \mathrm{s}$ in the equation described in "Methods" (extended NO analysis). ${ }^{* * *} p<0.001$ (Spearman rank).

extended NO analysis) and measured Feno at the targeted exhalation flow rate of $0.05 \mathrm{~L} / \mathrm{s}$. Even though these measured values had not been used to solve the estimated variables, the correlation was highly significant $(r=0.99, p<0.001)$.

\section{DISCUSSION}

A few previous studies in adults have demonstrated that Fawno, Fano, Dawno, and $\dot{V}_{\text {ENO }}$ max can be estimated noninvasively by measuring $\mathrm{NO}$ in exhaled air at multiple exhalation flow rates $(13-15,17,21)$. The physiologic model for these calculations is basically the same even though the mathematical solutions can vary among different research groups. The aim of our study was to investigate whether such variables could be estimated in schoolchildren and how asthmatic children differ from healthy control children. We also studied the influence of age and airway size on these variables and their relation to $\mathrm{FENO}_{0.05}$.

The asthmatic children showed higher values in all estimated variables except FANO. This is in good agreement with previous findings in adults $(14,17)$. An increase in Fawno in asthmatic subjects seems logical inasmuch as iNOS is induced in the bronchial epithelium in asthma (9). However, even though the groups were completely separate with respect to $\mathrm{FeNO}_{0.05}$, both Fawno and Dawno overlapped considerably. The discriminatory power of these two variables therefore seems to be lower than that of $\mathrm{FENO}_{0.05}$. Interestingly, Lehtimaki et al. (22) found increased FANO in patients with allergic alveolitis, using a similar model for NO diffusion. This shows that NO measurements at multiple flow rates can be of interest in other airway diseases as well because it seems possible to distinguish between alveolar and bronchial inflammation. Their data also validate the NO diffusion model.

The increase in Dawno, seen in asthmatic children, has been more of a challenge to explain. Jörres (15) speculated about influences of NO biochemistry, the total surface area excreting $\mathrm{NO}$, and the amount and quality of mucosal secretions. How- 
Table 2. Correlations between variables under study

\begin{tabular}{|c|c|c|c|c|c|c|}
\hline & \multicolumn{3}{|c|}{ Asthmatics } & \multicolumn{3}{|c|}{ Controls } \\
\hline & $r$ Value & $95 \% \mathrm{CI}$ & $p$ value & $r$ value & $95 \% \mathrm{CI}$ & $p$ value \\
\hline $\mathrm{FENO}_{0.05} v s \dot{\mathrm{V}} \mathrm{ENO}_{\max }$ & 0.95 & 0.85 to 0.98 & $<0.001$ & 0.98 & 0.93 to 0.99 & $<0.001$ \\
\hline $\mathrm{FENO}_{0.05} v s \mathrm{D}_{\mathrm{aw}} \mathrm{NO}$ & 0.65 & 0.18 to 0.87 & $<0.01$ & 0.48 & -0.05 to 0.80 & 0.07 \\
\hline VD vs $\mathrm{FeNO}_{0.05}$ & 0.05 & -0.48 to 0.56 & 0.85 & 0.68 & 0.24 to 0.89 & $<0.01$ \\
\hline $\mathrm{VD}_{\mathrm{D}} v s \dot{\mathrm{V}}_{\mathrm{ENO}} \max$ & -0.004 & -0.53 to 0.52 & 0.99 & 0.71 & 0.29 to 0.90 & $<0.01$ \\
\hline Age vs $\mathrm{FENO}_{0.05}$ & 0.02 & -0.51 to 0.54 & 0.94 & 0.74 & 0.34 to 0.91 & $<0.01$ \\
\hline Age $v s \dot{V}_{\text {ENO }}$ max & -0.12 & -0.60 to 0.44 & 0.70 & 0.76 & 0.40 to 0.92 & $<0.001$ \\
\hline Age $v s \mathrm{~F}_{\mathrm{aw}} \mathrm{NO}$ & 0.28 & -0.28 to 0.70 & 0.31 & 0.52 & 0.00 to 0.82 & $<0.05$ \\
\hline Age $v s \mathrm{D}_{\mathrm{aw}} \mathrm{NO}$ & -0.34 & -0.74 to 0.22 & 0.21 & 0.40 & -0.15 to 0.77 & 0.14 \\
\hline
\end{tabular}

CI, confidence interval.

ever, the influence of mucous secretions is probably small as NO diffuses rapidly into the gas phase (23).

Silkoff et al. (14) argued that an increase in NO release from inhibitory nonadrenergic noncholinergic nerve fibers could be involved. This notion was based on the observation that Dawno seemed unaffected by inhaled steroids and that Dawno, Fawno, and $\dot{\mathrm{V}}_{\mathrm{ENO}}$ max were negatively correlated with airway hyperresponsiveness. However, no other study has demonstrated a negative correlation between exhaled NO and airway hyperresponsiveness. Instead, previous investigators have found either a positive correlation $(7,24,25)$ or no correlation at all $(26,27)$ between exhaled NO and airway inflammation. In addition, nonadrenergic noncholinergic nerves are not found in the epithelium $(28,29)$, and because NO is rapidly metabolized within the tissue (30) or absorbed by $\mathrm{Hb}(31-33)$, it is doubtful that neuronal NO has the ability to reach the airway lumen. Instead, it is believed that iNOS, which is primarily found apically in the epithelial cells, is responsible for mucosal $\mathrm{NO}$ release in the airways (34).

In our study, children of various ages and with different lung volumes were investigated. A positive correlation between Dawno and VD could be demonstrated, but only in control children. Because $V_{D}$ is defined as the airway volume not involved in gas exchange, $V_{D}$ relates to the conducting airway surface area. We therefore suggest that the main determinant of Dawno is the total NO-releasing surface area. Even though the main source of NO is the upper airways (2), there is evidence of NO release from the lower airways in both asthmatic and healthy humans $(35,36)$. In healthy subjects, it is mostly the larger bronchi that release NO (36). We believe that the proportion of the airway surface area that is involved in NO release remains fairly constant during childhood, but we suggest that if the child becomes asthmatic, the formation of NO is extended to the peripheral airways. Consequently, the relationship between Dawno and VD disappears.

The relationship between Dawno and age, body size, or $V_{D}$ has not previously been studied, but it has been shown that adult men have higher Feno levels than women (37), even after the adjustment for body size (38). This might be explained by our finding that Dawno was associated with $V_{D}$ and that the $V_{D}$ in relation to body weight is greater in men (39).

Our data are also supported by observations from Franklin et al. (40), who found a positive correlation between Feno and age in 137 healthy children, and Kissoon et al. (41), who more recently showed similar results. In addition, we found that $\mathrm{FeNO}_{0.05}$ correlated better with Dawno in asthmatic children and with Fawno in control subjects, which indicates that the expansion in total NO-releasing airway surface area overrides the association between $\mathrm{FeNO}_{0.05}$ and Fawno in asthma. However, we believe that the $\mathrm{FENO}_{0.05}$ value, measured in an asthmatic or nonasthmatic individual, is determined by both Fawno and Dawno. Therefore, it is not surprising that such a strong correlation between $\mathrm{FeNO}_{0.05}$ and $\dot{\mathrm{V}}_{\mathrm{ENO}}$ max was found, as $\dot{\mathrm{V}} \mathrm{ENO}_{\max }$ depends on Fawno and Dawno.

It has been shown that $\mathrm{FENO}_{0.05}$, Fawno, and $\dot{\mathrm{V}}_{\mathrm{ENO}}$ max are decreased after treatment with inhaled steroids (14). However, Dawno seemed unaffected by this treatment (14). The reason for this is unclear. Future studies may reveal whether Dawno, in combination with $\mathrm{FeNO}_{0.05}$, would give a better measure of the degree and extension of asthmatic inflammation before and after the introduction of antiinflammatory treatment.

FENo values at three different exhalation flow rates were successfully incorporated in a two-compartment model for $\mathrm{NO}$ diffusion recently described by Högman et al. (17). The correlation between measured and expected $\mathrm{FeNO}_{0.05}$ was very strong, indicating that the accuracy of the measurements, the physiologic model, and the mathematical solutions should be adequate. Nevertheless, our data were originally obtained to study the reproducibility of $\dot{V}_{\text {ENO }}$ at different exhalation flow rates (20). Consequently, no reproducibility criteria for $\dot{\mathrm{V}}$ ENO were followed. Feno measurement under strict flow control may further improve $\dot{V}_{\text {ENO }}$ reproducibility and, thus, the accuracy of flow-independent variables estimated using mathematical solutions involving $\dot{V}_{\text {ENO }}$. Furthermore, future studies should determine the optimal exhalation flow rates used in $\mathrm{NO}$ diffusion model in different age groups to improve reproducibility.

\section{CONCLUSIONS}

We conclude that a more detailed picture of NO formation in the lower airways can be achieved noninvasively in children by measuring $\mathrm{NO}$ at multiple exhalation flow rates. Future investigations will clarify the clinical usefulness of these variables. In our hands, Dawno seems to reflect the extension of inflammation into the peripheral airways. 


\section{REFERENCES}

1. Gustafsson LE, Leone AM, Persson MG, Wiklund NP, Moncada S 1991 Endogenous nitric oxide is present in the exhaled air of rabbits, guinea pigs and humans. Biochem Biophys Res Commun 181:852-857

2. Alving K, Weitzberg E, Lundberg JM 1993 Increased amount of nitric oxide in exhaled air of asthmatics. Eur Respir J 6:1368-1370

3. Kharitonov SA, Yates D, Robbins RA, Logan-Sinclair R, Shinebourne EA, Barnes PJ 1994 Increased nitric oxide in exhaled air of asthmatic patients. Lancet 343:133-135

4. Mattes J, Storm van's Gravesande K, Reining U, Alving K, Ihorst G, Henschen M Kuehr J 1999 NO in exhaled air is correlated with markers of eosinophilic airway inflammation in corticosteroid-dependent childhood asthma. Eur Respir J 13:13911395

5. Payne DN, Adcock IM, Wilson NM, Oates T, Scallan M, Bush A 2001 Relationship between exhaled nitric oxide and mucosal eosinophilic inflammation in children with difficult asthma, after treatment with oral prednisolone. Am J Respir Crit Care Med $164: 1376-1381$

6. Silvestri M, Spallarossa D, Frangova Yourukova V, Battistini E, Fregonese B, Ross GA 1999 Orally exhaled nitric oxide levels are related to the degree of blood eosinophilia in atopic children with mild-intermittent asthma. Eur Respir J 13:321326

7. Jatakanon A, Lim S, Kharitonov SA, Chung KF, Barnes PJ 1998 Correlation between exhaled nitric oxide, sputum eosinophils, and methacholine responsiveness in patient with mild asthma. Thorax 53:91-95

8. Van Den Toorn LM, Overbeek SE, De Jongste JC, Leman K, Hoogsteden HC, Prin JB 2001 Airway inflammation is present during clinical remission of atopic asthma. Am J Respir Crit Care Med 164:2107-2113

9. Hamid Q, Springall DR, Riveros-Moreno V, Chanez P, Howarth P, Redington A, Bousquet J, Godard P, Holgate S, Polak JM 1993 Induction of nitric oxide synthase in asthma. Lancet 342:1510-1513

10. Guo FH, Comhair SA, Zheng S, Dweik RA, Eissa NT, Thomassen MJ, Calhoun W, Erzurum SC 2000 Molecular mechanisms of increased nitric oxide (NO) in asthma: evidence for transcriptional and post-translational regulation of NO synthesis. J Immunol 164:5970-5980

11. Silkoff PE, McClean PA, Slutsky AS, Furlott HG, Hoffstein E, Wakita S, Chapman KR, Szalai JP, Zamel N 1997 Marked flow-dependence of exhaled nitric oxide using a new technique to exclude nasal nitric oxide. Am J Respir Crit Care Med 155:260 267

12. Slutzky AS, Drazen JM, Silkoff PE, Gaston BM, Holden W, Romero FA, Alving K Baraldi E, Barnes PJ, Bratton D, Chatkin JM, Cremona G, de Gouw H, Deykin A, Djupesland P, Douglas J, Erzurum S, Gustafsson LE, Haight J, Hogman M, Irvin C, Joerres R, Kissoon N, Lanz MJ, Lundberg JON, Massaro AE, Mehta S, Olin A, Permutt S, Qian W, Robbins R, Rubinstein I, Sylvester JT, Townley R, Weitzberg E, Zamel N 1999 Recommendations for standardized procedures for the online and offline measurement of exhaled lower respiratory nitric oxide and nasal nitric bride in adults and children-1999. Am J Respir Crit Care Med 160:2104-2117

13. Tsoukias NM, George SC 1998 A two-compartment model of pulmonary nitric oxide exchange dynamics. J Appl Physiol 85:653-666

14. Silkoff PE, Sylvester JT, Zamel N, Permutt S 2000 Airway nitric oxide diffusion in asthma: role in pulmonary function and bronchial responsiveness. Am J Respir Crit Care Med 161:1218-1228

15. Jörres RA 2000 Modelling the production of nitric oxide within the human airways Eur Respir J 16:555-560

16. Högman M, Drca N, Ehrstedt C, Merilainen P 2000 Exhaled nitric oxide partitioned into alveolar, lower airways and nasal contributions. Respir Med 94:985-99

17. Högman M, Holmkvist T, Wegener T, Emtner M, Andersson M, Hedenstrom H, Merilainen P 2002 Extended NO analysis applied to patients with COPD, allergic asthma and allergic rhinitis. Respir Med 96:24-30

18. Lumb AB 2000 Nunn's Applied Respiratory Physiology, 5th ed. Reed Educational and Professional Publishing Ltd, Oxford, pp 178-179
19. Kharitonov S, Alving K, Barnes PJ 1997 Exhaled and nasal nitric oxide measurements: recommendations. Eur Respir J 10:1683-1693

20. Pedroletti C, Zetterquist W, Nordvall L, Alving K 2002 Evaluation of exhaled nitric oxide in schoolchildren at different exhalation flow rates. Pediatr Res 52:393-398

21. Shin HW, Rose-Gottron CM, Perez F, Cooper DM, Wilson AF, George SC 2001 Flow-independent nitric oxide exchange parameters in healthy adults. J Appl Physiol 91:2173-2181

22. Lehtimaki L, Kankaanranta H, Saarelainen S, Hahtola P, Jarvenpaa R, Koivula T, Turjanmaa V, Moilanen E 2001 Extended exhaled NO measurement differentiates between alveolar and bronchial inflammation Am J Respir Crit Care Med 163:15571561

23. Chung SJ, Fung HL 1990 Identification of the subcellular site for nitroglycerin metabolism to nitric oxide in bovine coronary smooth muscle cells. J Pharmacol Exp Ther 253:614-619

24. al-Ali MK, Eames C, Howarth PH 1998 Exhaled nitric oxide; relationship to clinicophysiological markers of asthma severity. Respir Med 92:908-913

25. Scollo M, Zanconato S, Ongaro R, Zaramella C, Zacchello F, Baraldi E 2000 Exhaled nitric oxide and exercise-induced bronchoconstriction in asthmatic children. Am J Respir Crit Care Med 161:1047-1050

26. Horvath I, Donnelly LE, Kiss A, Kharitonov SA, Lim S, Fan Chung K, Barnes PJ 1998 Combined use of exhaled hydrogen peroxide and nitric oxide in monitoring asthma. Am J Respir Crit Care Med 158:1042-1046

27. Silvestri M, Spallarossa D, Battistini E, Brusasco V, Rossi GA 2000 Dissociation between exhaled nitric oxide and hyperresponsiveness in children with mild intermittent asthma. Thorax 55:484-488

28. Fischer A, Hoffmann B 1996 Nitric oxide synthase in neurons and nerve fibers of lower airways and in vagal sensory ganglia of man: correlation with neuropeptides. Am J Respir Crit Care Med 154:209-216

29. Ward JK, Barnes PJ, Springall DR, Abelli L, Tadjkarimi S, Yacoub MH, Polak JM, Belvisi MG 1995 Distribution of human i-NANC bronchodilator and nitric oxideimmunoreactive nerves. Am J Respir Cell Mol Biol 13:175-184

30. Beckman JS, Koppenol WH 1996 Nitric oxide, superoxide, and peroxynitrite: the good, the bad, and ugly. Am J Physiol 271:C1424-C1437

31. Robbins RA, Floreani AA, Von Essen SG, Sisson JH, Hill GE, Rubinstein I, Townley RG 1996 Measurement of exhaled nitric oxide by three different techniques. Am J Respir Crit Care Med 153:1631-1635

32. Borland C, Cox Y, Higenbottam T 1993 Measurement of exhaled nitric oxide in man Thorax 48:1160-1162

33. Sharma VS, Traylor TG, Gardiner R, Mizukami H 1987 Reaction of nitric oxide with heme proteins and model compounds of hemoglobin. Biochemistry 26:3837-3843

34. Lundberg JO, Farkas-Szallasi T, Weitzberg E, Rinder J, Lidholm J, Anggaard A, Hokfelt T, Lundberg JM, Alving K 1995 High nitric oxide production in human paranasal sinuses. Nat Med 1:370-373

35. Kharitonov SA, Chung KF, Evans D, O'Connor BJ, Barnes PJ 1996 Increased exhaled nitric oxide in asthma is mainly derived from the lower respiratory tract. Am J Respir Crit Care Med 153:1773-1780

36. Silkoff PE, McClean PA, Caramori M, Slutsky AS, Zamel N 1998 A significant proportion of exhaled nitric oxide arises in large airways in normal subjects. Respir Physiol 113:33-38

37. Palm JP, Graf P, Lundberg JO, Alving K 2000 Characterization of exhaled nitric oxide: introducing a new reproducible method for nasal nitric oxide measurements. Eur Respir J 16:236-241

38. Tsang KW, Ip SK, Leung R, Tipoe GL, Chan SL, Shum IH, Ip MS, Yan C, Fung PC, Chan-Yeung M, Lam W 2001 Exhaled nitric oxide: the effects of age, gender and body size. Lung 179:83-91

39. Harris EA, Hunter ME, Seelye ER, Vedder M, Whitlock RM 1973 Prediction of the physiological dead-space in resting normal subjects. Clin Sci Mol Med 45:375-386

40. Franklin PJ, Taplin R, Stick SM 1999 A community study of exhaled nitric oxide in healthy children. Am J Respir Crit Care Med 159:69-73

41. Kissoon N, Duckworth LJ, Blake KV, Murphy SP, Taylor CL, De Nicola LR, Silkoff PE 2002 Exhaled nitric oxide concentrations: online versus offline values in healthy children. Pediatr Pulmonol 33:283-292 